\title{
A networking model. The case of the I nternational Center for Genetic Epistemology
}

\section{Um modelo de rede. O caso do Centro Internacional de Epistemologia Genética}

\section{Un modelo de red. El caso del Centro Internacional de Epistemología Genética}

\author{
Marc J . Ratcliff* \\ University of Geneva - UNIGE, Genebra, Suíça \\ Ramiro Tau** \\ University of Geneva - UNIGE, Genebra, Suíça
}

\begin{abstract}
The article reviews the process of conformation of the International Center for Genetic Epistemology (CIEG), which functioned at the University of Geneva between 1955 and 1986. This Center led by Jean Piaget had the collaboration of hundreds of researchers from around the world and from different disciplines. We will here review the configuration of the centripetal circuits that led to the constitution of an institution with a double centrality. On the one hand, taking into account the history of international scientific circulations, it is feasible to recognize in the CIEG a reference point from which the radial journeys of social exchanges with different scientific communities can be reconstructed. On the other hand, we can identify a research program that positioned psychology at the core of epistemological debates. To contribute to the historical analysis of this double movement of centration, geography and theory, we examine the development of a series of strategies tending to the start-up of the Center, deployed during the first years of the 1950s.
\end{abstract}

Keywords: International Center for Genetic Epistemology, CIEG, History, Piaget - Genetic epistemology, Psychology.

\section{RESUMO}

O artigo analisa o processo de constituição do Centro Internacional de Epistemologia Genética (CIEG), localizado na Universidade de Genebra entre 1955 e 1986. Este centro liderado por Jean Piaget contava com a colaboração de centenas de pesquisadores de todo o mundo e de diferentes disciplinas. Aqui, revisaremos a configuração dos circuitos centrípetos que levaram à constituição de uma instituição com dupla centralidade. Por um lado, levando em conta a história das circulações científicas internacionais, é viável reconhecer no CIEG um ponto de referência a partir do qual as viagens radiais de trocas sociais com diferentes comunidades científicas podem ser reconstruídas. Por outro lado, podemos identificar um programa de pesquisa que posicionou a psicologia no centro dos debates 
epistemológicos. Para contribuir com a análise histórica desse duplo movimento de centralização, geografia e teoria, examinamos o desenvolvimento de uma série de estratégias, do Centro, implantadas nos primeiros anos da década de 1950.

Palavras chave: Centro Internacional de Epistemologia Genética, CIEG, Historia, Piaget - Epistemologia Genética, Psicologia.

\begin{abstract}
RESUMEN
El artículo revisa el proceso de conformación del Centro Internacional de Epistemología Genética (CIEG), radicado en la Universidad de Ginebra entre 1955 y 1986. Este Centro liderado por Jean Piaget contó con la colaboración de cientos de investigadores de todo el mundo y de diversas disciplinas. Aquí, nos ocuparemos de revisar la configuración de los circuitos centrípetos que desembocaron en la constitución de una institución con una doble centralidad. Por un lado, atendiendo a la historia de las circulaciones científicas internacionales, es factible reconocer en el CIEG un lugar de referencia desde el cual pueden reconstruirse los trayectos radiales de intercambios sociales con diferentes comunidades científicas. Por otra parte, podemos identificar un programa de investigación que posicionó a la psicología en el núcleo de los debates epistemológicos. Para contribuir al análisis histórico de este doble movimiento de centralización, geográfica y teórica, examinamos el desarrollo de una serie de estrategias tendientes a la puesta en marcha del Centro, desplegadas durante los primeros años de la década de 1950.
\end{abstract}

Palabras clave: Centro Internacional de Epistemología Genética, CIEG, Historia, Piaget - Epistemología Genética, Psicología.

The International Center of Genetic Epistemology (hereinafter CIEG, by its original name in French), founded by Jean Piaget at the University of Geneva at the end of 1955, configured a type of knowledge production unique in its kind (Bronckart, 1980, Dionnet, 1998). This statement is not intended to be a celebration of the theoretical perspective developed there, but rather the recognition of the effects of an institutional device for scientific collaboration that systematically, and for three decades, redefined the relationships between psychology and theory of knowledge (Hofstetter, Ratcliff, \& Schneuwly, 2012).

Even though it is usually pointed out that one of the most original aspects of the work developed in the CIEG consisted of having appealed to psychology for the development of an epistemological program, it is necessary to remember that this approach was not entirely new. Indeed, as early as 1890 , the psychologist James Mark Baldwin, author who Piaget read early on (Piaget, 1923), had formulated a genetic psychology and epistemology, centered on the development of knowledge (Burman, 2013). During the First World War, the Italian philosopher and mathematician Federigo Enriques also tried to build an associationist epistemology of a scientific nature, based on the development of children's notions. However, these epistemological projects, and especially that of Baldwin, which 
aspired to compare or analyse the evolution of the child's thinking with that of civilization, remained forgotten and did not yield any concrete results, except some philosophical discussions that did not mark profoundly the developments of psychology or of epistemology. Anyway, although it is not necessary to insist that the theoretical principles proposed by these authors were not the same as those formulated by Piaget, at least in a general way, it is possible to admit that, with the creation of the CIEG, Piaget partially revitalized these attempts of a theory of knowledge supported by psychology. That is why the originality of this institution must be sought, not so much in the attempt of coordination between psychology and epistemology, but in the social and theoretical dynamics to which that proposal led. Following this idea, in this article we will review the configuration of the centripetal circuits that led to the constitution of an institution with a double centrality. On the one hand, taking into account the history of international scientific circulations, it is feasible to recognize in the CIEG a geographical center, a reference point from which the radial journeys of social exchanges with different scientific communities can be reconstructed. On the other hand, we can identify a research program that positioned psychology at the core of epistemological debates. In this sense, the CIEG did not promote a simple appeal to psychology as just one of the various fields of expert knowledge, but instead set it up as the probative place for a nonspeculative theory of knowledge. To contribute to the historical analysis of this double movement of centration, geography and theory, we will next examine the development of a series of strategies tending to the start-up of the Center, deployed during the first years of the 1950s.

\section{The CI EG and its multiple edges}

The extension and variety of the Piagetian work makes any attempt at rapid definition difficult. In the words of Emilia Ferreiro, Piaget

[...] is for some, a Kantian idealist; for others, a dialectical thinker who situates himself in the direct continuation of Marxist materialism; he is, for some, the one that formulates the scientific bases of an active pedagogy and, for others, the defender of a development process with respect to which the school has nothing to do $[\ldots]$. (Ferreiro, 1975, p. 5 $\left.{ }^{1}\right)$.

In a sense, all these characteristics are partially correct and referto a perspective in which multiple disciplines converge. The diversity of theoretical and practical interests is rediscovered, in the manner of a 
fractal, in the dynamics adopted by the exchanges that Piaget established with other researchers. The CIEG is the institution that undoubtedly best represents the interdisciplinary and reticular collaboration that is in accordance with its theoretical approach. This characteristic was, at the same time, the source of an inevitable complexity. Already at the beginning of the first of the 37 volumes published by the Center-the Studies of Genetic Epistemology (Fondation Archives Jean Piaget, 1989) - the reader was warned about the peculiarity of the project:

Thanks to the generous help of the Rockefeller Foundation, the Faculty of Sciences of Geneva has been able to create in 1955 an "International Center of Genetic Epistemology". This title is a little complicated, because the type of investigations to which it refers is, in itself, complex [...]. The objective of this Center in Geneva is to ensure the possibility of teamwork among specialists from different horizons, in order to address, for a given time, the study of the issues delimited by scientific epistemology, from the perspective of development. More specifically, the Center strives to organize, year after year, the collaborative work of psychologists and representatives of some other particular science, for the study of some epistemological problem related to this second discipline, choosing preferably the problems that can be addressed from genetic way (Beth, Mays, \& Piaget, 1956, p. 1-2 ${ }^{1}$ ).

In these inaugural lines, there is an evident epistemological focus of the proposal, an interdisciplinary collaboration to which it aspires and the capital function of psychology within the program. Less clearly, some of the lines that would derive from the Center are also anticipated. This is brought forward by a set of publications that historicize its different dimensions: political, cultural and scientific, among others.

Regarding this field of historical research on the CIEG, and by way of synthesis, it is possible to establish five broad categories. In the first place, we distinguish the studies that reconstruct the intellectual history of the Center (Bronckart, 1980; Monnier \& Wells, 1982; Ducret, 1998, 2000). On the other hand, from a more than historical perspective, Dionnet (1998) analyzes their modes of social functioning, while Hofstetter, Ratcliff and Schneuwly (2012) highlight the role of funding in the development of research. A third series of explorations, carried out by various authors until the 1990s, refer to the place that the Piagetian genetic epistemology occupied in the field of philosophy of science (Brief, 1977; Gagnon, 1977; Kesselring, 1981; Apostel, 1982; Bickhard, 1982; Fetz, 1982; Vonèche, 1985; Grize, 1996; Perri, 1996; Dell'Omodarme, 2014). Fourth, we can 
recognize a group of inquiries focused on the interdisciplinary dimension adopted in the CIEG (Vonèche, 1993; Darbellay, 2011; Ratcliff, 2016). Finally, some works focus on the origin, but of the genetic epistemology project that was deployed there rather than that of the CIEG, showing the relationship of affiliation to this point of view with that of other thinkers, such as Alfred Binet (Smith, 1994), Henri Bergson (Ducret, 1983; Vidal, 1996) or James Mark Baldwin (Burman, 2016; Carpintero \& Peiro, 1977).

However, there are no studies that have dealt with the genesis of the CIEG, the concrete manoeuvres and social work that implied, for Piaget, moving from a utopic idea of his youth to its realization. Considering this vacancy, in these pages, we will try to answer the problems implied in the following question: what were the political and institutional strategies that allowed to ensure the creation of the CIEG and what conceptual and human resources contributed to the configuration of its theoretical and geographical centrality? To do this, we will review the vicissitudes of its constitution, paying particular attention to two aspects that we consider to be defining: a) the gradual construction of a network of collaborations with a focus and various nodes; b) the type of social relations that the Center promoted and the consequences of this for theory and, especially, for psychology.

\section{The roots of the Center and its constituent lines}

To understand how Piaget came to conceive an academic organization like the CIEG, it is necessary to point out that in his work it is possible to trace early an insisting idea: to unite science under a new epistemological flag. Without pretending to recreate the readings that tried to show that the thought displayed by Piaget was already announced and even prefigured since his first works, we think it appropriate to briefly recall some precursory ideas of what would be his epistemological project.

During the First World War, Piaget wrote a novel entitled Recherche, which was published in 1918. In this fictional work some of the themes that would be reissued later in his scientific program are announced: the search for the reasons, the truths, the foundation of the sciences and the deeply social character of objective knowledge. Loosely mentioned are certain notions that later would be central, such as equilibrium (Vonèche, 1996), that of a distance between action and reflection or its circular conception of scientific disciplines, an idea that will reappear thirty years later, perfected in his Introduction to Genetic Epistemology (Piaget, 1950c).

From the 1920s, Piaget moved from biology to other sciences and concentrated on the reading of scientific, epistemological, 
philosophical, logical, pedagogical, sociological, anthropological and, of course, psychological works. In parallel, he was in charge of teaching courses on sociology, psychology and philosophy of science at the University of Neuchâtel. In 1929 he was appointed director of the International Bureau of Education and was appointed, at the University of Geneva, to an academic position of history of scientific thought (Ratcliff \& Borella, 2013), which contributed to the establishment of his earlier concerns.

Later in the 1930s, Piaget was progressively oriented himself towards the problems of natural logic, participating, in its own way, in the process of formalization of science that was produced with the work of the Vienna Circle (Ratcliff, 2016). In this context, together with his wife, the psychologist Valetine Châtenay, he made a careful longitudinal investigation of sensorimotor child behaviours. Meticulously documented in 10 notebooks containing about 10,000 systematic observations, these field annotations formed the empirical basis for theorizing the genesis of preverbal intelligence. Through the analysis of these data, he elaborated his hypothesis about the construction of the natural logic of the subject. A testimony of this are his works on the reversibility of operations (Piaget, 1938), the construction of classes, relationships, transformations and numbers (Piaget, 1942, 1949, 1952), crowned by Logic and psychology, a monograph originally published in English (Piaget, 1953) integrated by the transcription of three lectures delivered in Manchester in 1952. The American and European reception of these works of the first half of the 20th century was very heterogeneous, and the line of demarcation was given by neo-positivism. In fact, most of the authors affiliated with the theses of the Vienna Circle, refused to consider Piaget's logic, much less the general cognitive theory that it implied. However, far from being discouraged, in 1950 the Presses Universitaires de France publishing house published his work in three volumes, Introduction to Genetic Epistemology (Piaget, 1950a; $1950 b ; 1950 c)$, a fundamental pillar for the future construction of the CIEG. In this triptych that deals with mathematical, physical, biological, psychological and sociological knowledge, emerged the lines of a research plan that cannot be traced without the collaboration of various experts. What was presented there was the proposal of an epistemology understood as a discipline to which the same canons of rigor must be applied as to the other sciences, based on empirical testing (García, 2001). At the same time, accentuating the dimension of the processes, it argues that it is essential to consider all knowledge from the point of view of its development over time (Piaget, 1950a). In other words, it proposes to study the "construction of all the essential notions or categories of thought" (Piaget, 1950a, p. 16-17 ${ }^{1}$ ), from the angle of its genesis. 
For this, Piaget had in 1950 three decades of experience in the investigation of the development of children's knowledge, which allowed him to anchor his project in the soil of long-considered hypotheses. Thus, twenty years before Quine proposed a naturalized epistemology -that is, "scientific" thanks to behavioural psychologyPiaget explicitly formulated a project of non-speculative epistemology, combining an empirical practice with a rigorous theory. However, a novelty is added to previous inquiries. The question about genetic tracing is a specific brand of this initiative. Indeed, although historians of science employ a genealogical method to "follow the development of the notions employed in a science" (Piaget, 1950a, p. $15)$, this strategy is insufficient. Mainly because "it refers to the notions constructed and used by a thought already constituted, that of the scientists themselves" (Piaget, 1950a, p. $15^{1}$ ). Here is one of the methodological nodes of the process. The history of science does not deal with genesis, because it cuts only the final product and the conditions of formation - the theoretical results, even the false ones, of an already established thought. Also, history has access to productions, which were mostly successful, something that masks a large part of its origin. On the contrary, to understand the genesis implies an investigation about its ways of constitution. This point makes, in its very formulation, a critique of the history of ideas, not because it considers it illegitimate, but because it is insufficient for understanding the process of forming concepts and notions. Thus, the historical-critical method must be complemented in order to explain the facts and not simply describe them.

We see that this general orientation necessarily implies interdisciplinarity, because it presupposes the confrontation between experts specialized in a specific already established field -the scientists-, and experts specialized in the process of constitution of thought -the psychologists. Therefore, to create this new scientific discipline, social arrangements were needed and Piaget maneuvered in advance in that direction. It would be necessary "to renounce certain discussions that divide the spirits and commit, by convention or gentleman's agreement, to speak only of the questions accessible through the exclusive use of certain common or communicable methods" (Piaget, 1950a, p. $9^{1}$ ). Piaget needed the collaboration of expert scientists in their areas in order to test the theses developed in his more than 15 books on children's thinking. This interdisciplinarity will be reflected, finally, in three areas of the life of the CIEG: a) in the publication committee of the series of volumes entitled "Studies of genetic epistemology", b) in the list of annual topics dealt with -many times problems of particular sciences-, and, c) in the diversity of theoretical orientations of the researchers who were present. 
The publications committee, formed between 1954 and 1957, was constituted as follows:

Table 1

Publications committee of the CIEG, formed between 1954 and 1957.

\begin{tabular}{llll}
\hline Name & Ciry & Country & Discipline \\
\hline Bachelard, Gaston & Paris & France & Epistemology \\
Bertal anffy, Ludwig von & Los Angeles & USA & Cybernetics \\
Beth, Evert Willem & Amsterdam & Holland & Logic, Psychology \\
Bouligand, Georges & Paris & France & Mathematics \\
Brumer, Jérome & Harvard & USA & Psychology \\
Ceccato, Silvio & Milan & Italy & Lingui stic \\
Fraisse, Paul & Paris & France & Psychology \\
Gonseth, Ferdinand & Zurich & Switzerland & Epistemology, Math \\
Hempel, Carl Gustav & Princeton & USA & Logic \\
Koehler, Otto & Freiburg & Germany & Zoology \\
Kotarbinski, Thaddeus & Warsaw & Poland & Logic \\
Lorenzen, Paul & Kiel & Germany & Mathematics \\
Miller, James Grier & Michigan & USA & Psychology \\
Naess, Arne & Oslo & Sweden & Epistemology \\
Perelman, Chaim & Brussels & Belgium & Lingui stic, Philosophy \\
Ryle, Gilbert & Oxford & United Kingdom & Philosophy \\
Quine, Willard & Harvard & USA & Logic \\
Vuysje, David & Amsterdam & Holland & Psychology \\
\hline
\end{tabular}

In this way, the repertoire of identities and basic disciplines of the members of the committee -among which are emerging areas, such as cybernetics- shows the breadth of coexisting perspectives in the editorial work:

Table 2

Basic disciplines of the members of the publications committee of the CIEG.

\begin{tabular}{|c|c|c|}
\hline Field & Represen & \\
\hline & $\begin{array}{l}\text { Beth, Evert Willem } \\
\text { Bouligand, Georges }\end{array}$ & \\
\hline & Gonseth Ferdinand & \\
\hline Logico-m athem atical Sciences & Hempel, Carl Gustav & 7 \\
\hline & Kotarbinski, Thaddeus & \\
\hline & Ouine. Willard & \\
\hline & Bruner, Jérome & \\
\hline Psychol ogy & Vuysie, David & 4 \\
\hline I yoniogy & Miller, James Grier & + \\
\hline & $\begin{array}{l}\text { rraisse, Paul } \\
\text { Bachelard Gaston }\end{array}$ & \\
\hline Epistem ology and philosophy & Naess, Arne & 3 \\
\hline & Ryle, Gilbert & \\
\hline Linguistics & Ceccato, Silvio & 2 \\
\hline & Perelm an, Chaïm & \\
\hline Physical-natural sciences & $\begin{array}{l}\text { Koehler, Otto } \\
\text { Bertal anffy, Ludwig von }\end{array}$ & 2 \\
\hline
\end{tabular}


On the other hand, during the years of the existence of the CIEG, the multiple theoretical questions addressed in its meetings were connected in an alternative way with a large number of theories and disciplines, although always based on a fundamental epistemological concern. It is sufficient to recall only some of the topics discussed annually -and that were, in addition, the central topics of the institutional publications-, in order to appreciate how the specific problems of particular sciences were used as a heuristic guide for the development of a general theory of knowledge. Among them, we can mention the hypothesis about information and its relation to the language, the probability models and the genesis of the numerical structures, the physical causality and the historical explanation, the contradictions, the generalizations or the identity problem in everyday and scientific thinking.

\section{Networking strategies}

As we saw, the project of a Center was not born suddenly, but it was the slow maturation of a perspective, which yielded the collaborative work. The geographical, conceptual and symbolic circulation along the paths of interdisciplinarity gradually constituted a requirement consistent with the Piagetian theory. But how would this utopia come about?

In the mid-twentieth century, Europe was experiencing a period of post-war reconstruction. The project for the preparation of the Epistemology Center was part of a general movement to restore the meeting points and academic work. In this context, the creation of institutes, seminars, research groups, formal or informal, was strongly promoted. Far from the version of the knowledge that emanated from his work of youth Recherche, Piaget explored directly the dynamics of different possible models for the Center, participating actively in associations of experts. In Geneva and Switzerland, he was a member of many scientific organizations: the respected Society of Physics and Natural History (created in 1793), the organization he presided over during the War, the societies of naturalists, philosophy, sociology and geography, as well as of new emerging institutions, among which stands out the Swiss Society of Psychology, of which he was one of its founders, in 1941. In Paris, he also participated in various philosophical and psychological groups. However, these scientific entities based on a monodisciplinary framework were not the appropriate social model for the interdisciplinary Center. For their part, political organizations such as the International Bureau of Education (IBE), of which he was director since 1929, or UNESCO, where he worked between 1945 and 1951, despite having 
international characteristics, did not serve as an archetype, since they were not designed for the development of research.

After the war, Piaget multiplied informal contacts with many colleagues and, especially in Paris, he participated in formal and informal groups and seminars: among them, Claude Lévi-Strauss's seminar on the use of mathematics in science. He also established relations with the mathematician Guilbaud, with the cybernetics of the 1950 s and the group Destouches-Février. In Switzerland, he collaborated with the team of Gonseth, and was part of the informal group of Bern, which from 1949 to 1952 brought together psychologists, physicians and physicists, such as Mercier, de Muralt and Scherrer, president of the Swiss Atomic Energy Commission. During these years, he expanded his social experience in networks and other forms of circulation and linking of actors around objects of knowledge, by direct interest or as a way to find a suitable operating model for his Center project.

The new social dynamic of the early 1950s allowed a series of international circulation axes to unfold around the figure of Piaget, who travelled throughout Europe and, since October 1952, frequently travelled the route linking Geneva with Paris, to teach at the Sorbonne. As we will see, the Center will be born thanks to what these axes promoted, focusing on five key regions: Manchester, Paris, Amsterdam, Brussels and the United States.

However, the difficulties did not only come from the management field. The theoretical resistances had also to be overcome in order to count on the collaboration of experts from all over the world. The establishment of a constructivist, interdisciplinary epistemology, linking the natural sciences with the psychology, logic and history of science, was not an easy task. The central genetic thesis, that is, the one that accounts for the construction of knowledge, was presented at a time when formalisms could only reject it. It was precisely those years that produced the structuralism that later became, during the 1960 s, an unavoidable "fashion".

The Piagetian publications of the late 1940s, Traité de logique (1949) and the Introduction to Genetic Epistemology (1950a, 1950b, 1950c), established the intellectual foundations. Likewise, it was the reactions to these same works that shaped the global space of reception of Piagetian thought in relation to logic and the theory of knowledge. Directed by Quine and Hempel, the Journal of Symbolic Logic rejected, since the early 1940 s, the logical theses presented in these works. The Treaty of Logic and Genetic Epistemology had a similar treatment, and, in addition, it was a publication ignored by the Americans. The conflict of paradigms was evident and for that reason, during the first years of the Center, the main productions were objections to the logical empiricism and its visceral distrust towards any form of psychology. In order to revise these differences, Piaget 
invited the main representatives of this trend - Quine, Hempel, Carnap, Beth - to place the confrontation between peers in the place of an absolute social value cultivated in the CIEG. But for this, it was necessary a constant activity of recruitment and establishment of bonds and institutions.

We will now review the deployment of these interaction and persuasion strategies around the five regions mentioned above.

\section{Manchester}

In the framework of the manoeuvres to promote discussions with the representatives of logical empiricism, we will see that before taking the corresponding invitations, Piaget personally approached their institutions. This was the case of the three conferences on logic and psychology he gave in Manchester in October 1952, invited by Michael Polanyi. These presentations were transcribed and translated into English at the end of 1952 by the philosopher and logician Wolfe Mays, with the help of Withehead (Mays, W. to J. Piaget, 22th February 1953) and were complemented by an introduction by Mays in which he explained the conceptions Logic of the Genevan Constructivism (Mays, W. to J. Piaget, 11th August 1953). In March 1953, Polanyi received the typed text to proceed with its publication (Polanyi, M. to J. Piaget, 6th March 1953). In the document entitled "Center Project" (probably from the spring of 1953), Piaget quotes Polanyi, who "is currently preparing an English edition of these lectures" (Piaget, 1953a). Polanyi wanted to send the translation to Alistair Crombie, the historian of science editor of the British Journal for the Philosophy of Science, although finally the lectures were published as a book by the Manchester Press (Polanyi, M. to J. Piaget, 6th March 1953).

Mays impressed Piaget very well. His simultaneous understanding of the Genevan constructivism and logical empiricism made him an ideal candidate to officiate as a conceptual translator, capable of confronting Piagetian ideas with Anglo-Saxon thought. Well-versed in symbolic logic, Mays was the right man to start a collaboration, since, in addition, Piaget did not speak or write in English, something necessary to start the engines of the Center.

In February, Piaget offered to explore "the possibility of establishing an international center of genetic epistemology in Geneva" (Mays, W. to J. Piaget, 22th February 1953). Sometime later, in April 1953, Mays traveled to Geneva to develop the institutional proposal. During this three-month stay, he became a friend, among others, of Bärbel Inhelder,-who would later visit Manchester, in early 1955 . This visit by Mays was followed by that of other actors, such as the psychologist John Cohen, who visited Geneva in 1954, linking up with 
Piaget, Inhelder and other collaborators. As reflected in several letters, in those years, the receptivity and hospitality of the Swiss team were as famous as their dynamics and production of knowledge. Contacts with the United Kingdom were numerous, especially through actors invited to Geneva as part of the WHO Study Group on Child Psychobiology since 1952: John Bowlby (London), Gray Walter (Bristol), Jim Tanner (London), George R. Hargreaves (Leeds). Piaget had also met Alan M. Turing -who died in 1954- and had planned to invite him to the future Center (Piaget, 1953). In this way, Manchester provided a reserve of representatives for a decade, exhausting this cooperation in the mid-1960s.

Of all these actors, Mays played the most important role, as the author of translations into English and as the person in charge of the financial requests for research. He was present at the Center the first year (1955-1956) and at the symposium in 1956, he participated in the production of the first books of the series Etudes, in 1957, about the relations between the logic of the subject and symbolic logic.

From that moment, the problems related to the construction of the notions of time, space and causality were discussed and analyzed through experimental designs. To do this, Piaget surrounded himself with physicists and psychologists from Manchester or contacted through the English. Among them were Eric Lunzer (1960-61), John Cohen and Kathleyn Henry (1961-62) and Charles Leggs, a student of Cohen (1963). The circuit followed by the members of the University of Manchester shows the system of circulations used by Piaget, in which the alternations between colleagues of the same university guaranteed a stable relationship.

\section{Belgium}

Contacts with Belgium date back to 1928 , when Piaget was invited to inaugurate a psychology center at the University of Liège, at a time when intra-wars networks were expanding. In Leuven, Piaget met Michotte and his students, Gerard de Montpellier and Joseph Nuttin. But Piaget was not only interested in attracting psychologists, but also philosophers, logicians and epistemologists. Among his friends was the linguist Chaim Perelman, with whom he met around 1945 in Zurich, within the framework of one of the Philosophical Science Congresses organized by the philosopher Ferdinand Gonseth. In this regard, Perelman sent Piaget his book On Justice, which includes the following dedication in handwriting: "to Professor Piaget, as a reminder of our meeting in Zurich". Through Perelman, Piaget contacted a young defender of logical empiricism, Leo Apostel, whom he sought to discuss on several occasions. As soon as the Traité de logique was published, Piaget sent it to Perelman, who forwarded it to 
Apostel, who was his [Perelman's] assistant at that time. After reading it, Apostel wrote a critical comment of more than twenty pages, seeking to define the specific aspects of the project (Ratcliff, 2016). Piaget took the criticism very well and, at the same time, found certain clues of the actors with whom a fruitful dialogue could be created. A few years later, Leo Apostel became editor of the magazine Logique et analyse and one of the most solid pillars of the CIEG, present since its inception and always sharp in its observations. The exchanges between Geneva and Belgium took place in both directions. On the one hand, at the time of the constitution of the CIEG, Piaget was present in some colloquia of the Belgian academy. In May and June 1953, he gave three lectures at the National Center for Research and Logic, at the Institute of Higher Studies of Belgium (Borren, C. van den to J. Piaget, 10th November 1952) and at the University of Brussels. These activities did not go unnoticed. The mass media echoed of them and, for example, at the beginning of June, lectures in Belgium were announced by one of the Geneva newspapers of the time (Journal de Genève, 4-6-1953).

On the other hand, the psychologists Gérard de Montpellier (symposium of 1958), A. Jonckheere (1958-59), the mathematicians Philippe Devaux (symposium of 1958) and Paul Libois (symposium of 1961) participated in the tasks of the CIEG. Leo Apostel cooperated constantly: he attended 18 symposiums for 25 years. Together with Bresson, Greco and Grize, it was one of the non-Geneva pillars for the sustainability of the activities. Later, in the late 1960s, a new generation of Belgian researchers, critical of Piaget, nurtured the Center's approaches with discussions and renewing perspectives: Marc Richelle, Jacques Voneche, Jean-Paul Bronckart, Wilhelm Doise, Jacques-Dominique de Lannoy.

\section{Amsterdam}

At the end of the Second World War, Dutch scientists also rewoven local and international ties with the dawn of pre-war societies. Thus, the Sociéte International de Signifique was reborn in the spring of 1946, when Synthèse published a manifesto for the creation of the International Society for the Study of Significs (AA.VV., 1946, p.96) -the legacy of a first society born around Brouwer and Mannoury- to which Piaget was invited. It is a nucleus with a Dutch center, connected as a network with France (Boasson, Bourgin, Destouches), Germany (Karl Dürr), United States (Rapoport, Raven), Switzerland (Gonseth, Mercier, Piaget) and Japan (Hayakawa). Piaget participated in several of the first conferences of this society and found the group extremely dynamic and sympathetic, although a bit idealistic (Piaget 1953, 5). However, when in the spring of 1954 Vuysje invited him 
again for the summer session of that year, he was forced to reject the offer (Piaget, J. to D. Vuysje, 18th May 1954). His commitments with UNESCO and Zurich were a priority in front of these meetings. Anyway, the collaborations were not interrupted. Indeed, Piaget was also a member of the editorial committee of Synthèse magazine, the organ of society, which began its publications in 1946, and included the logicians Beth and Feys, Jean-Louis Destouches and the philosopher Eugene Dupréel.

The episode of the controversy between Beth and Piaget after the publication of Traité de logique in 1949, transformed into a misunderstanding and metamorphosed into collaboration, is full of clues to understand the strategies of perseverance behind the creation of the CIEG (Ratcliff, 2016). Piaget's interest in logic and formal analysis developed from the 1930s, led him to publish in 1949 a very unorthodox treaty, by bringing logic to the terrain of organizations built by the subject, such as the reversibility of specific operations and the INRC transformation group. Quickly, these were noticed by Beth (1950), who adopted an explicitly critical position. After reading one of these discussion articles, Piaget wrote a reply sent to Methods that was rejected. He decided, then, to send that same text directly to Beth, and offer to work together to clarify his views. Since 1940, the neopositivists had pointed out the triviality of the Piagetian works of logical cut, whereas the French logicians were modifying their opinions: "in this way it is demonstrated that the logistics can be something more than a well-done language: (...) his operations correspond to the real operations of thought" (Anonymous 1954, 459). However, it was Beth's objections - as well as Apostel's, privately held - that provided a source of genuine discussion with European specialists in logical empiricism. Piaget's strategy, in these situations, was always to invite collaboration to be understood and not avoid the approaches (Ratcliff, 2016). Eternally ready for confrontation, Piaget was attentive to all truly critical authors who could present divergent arguments, even in those cases in which disciplinary specialization made them speak a different language. In other words, Piaget developed a vast dialogical capacity together with the tools of social identification of competent actors. This was another way in which circulations around Geneva increased. In Beth's case, it was the beginning of constant cooperation and friendship that lasted until his death in 1964.

\section{New York}

The cultural policy of the Rockefeller Foundation, whose scholarships and funds for Europe reached $\$ 250$ million annually during the 1950 s, was one of the pillars for the reconstruction of Europe. These 
programs were an extension of the Marshall Plan through a commitment to the private sector. There are many studies that have reviewed the use of this soft-power or neo-imperialism, in the struggle against the Soviet influence and the dismantling of any alternative that would disturb the constituted hegemony and the economic order sought. In this situation, organizations such as the Rockefeller Foundation were the financial support (Matsuda, 2007; Tucker, 1997), in part, for the intellectual recovery of Europe, through the creation or restoration of laboratories, institutes or other centers of knowledge. Among these was the CIEG.

In Geneva, a place favoured by the presence of the "Piaget industry" (Ratcliff, 2011) -where the students and assistants were trained in the clinical method and in the thesis of genetic epistemology- there was a lack of space and economic means. At that time, the Swiss National Fund for Scientific Research, provider of economic subsidies, was at its beginnings and the type of structure that Piaget intended involved resources and constant displacements. For this reason, the private subsidy was used. From 1935 to 1938, Piaget had had some contacts with the Rockefeller Foundation to which he had applied for funding for the Rousseau Institute (Hofstetter, 2010, p. 268).

In the fall of 1952, Piaget and John Marshall, director of humanities at the Rockefeller Foundation, met in Paris (Marshall, J. at J. Piaget, 9th January 1953). In December 1952, Piaget sent him an essay on the importance of epistemology, which generated much discussion and Marshall responded in January clarifying the position of the Foundation: assessing the "possibility of such an investigation" (Marshall, J. at J. Piaget, 9th January 1953). However, Piaget's project was not entirely clear to them: "we are not convinced of fully understanding what you have in mind" (Marshall, J. at J. Piaget, 9th January 1953). Also, Introduction to genetic epistemology was a work unknown in the United States, no copies could be found in New York and there was no report on it. Piaget also had not gone into details about the American work in the scientific field, something that surprised Rockefeller: "In a few words, have you been able to follow the publications related to epistemology in the United States during the last years?" (Marshall, J. to J. Piaget, 9th January 1953). This is undoubtedly one of the most representative phrases of what was Piaget's American policy in that context, which prompted him, for almost two decades, to progressively approach US researchers. Along the same lines, Gilpatrick considered that many American studies, including technical ones, could be used by Piaget, and "instead of seeking to formulate projects from the beginning in the long term, as the center you propose" (Marshall, J. at J. Piaget, 9th January 1953) he suggests him to research published literature and getting in touch with experts on the subject. Among the examples mentioned was the Arne Naess group in Oslo. 
Marshall could not predict anything, but he stressed that the overall importance of the project was clear to them, and that they were willing to offer him the means to carry it forward. To do this, they proposed to Piaget to travel to the United States and visit some research institutes in Europe, such as the one in Oslo. In this way, he was offered the conditions for an exploratory circulation. Thus, during the year 1953, among many other tasks -monitoring of research programs in Geneva, teaching in Switzerland and France, the direction of the BIE and the intense life of scientific societies- Piaget made multiple trips, with the blessing of the directors of Rockefeller, in several centers in Europe.

\section{The drafting of the project and the confidential report}

These contacts with Rockefeller seemed to be the best solution, although there was a considerable obstacle: as we have seen, Piaget did not speak English. Even knowing the language, he refused to speak English, as pointed out by Jan Smedslund, a collaborator of Naess, regarding his trip to Oslo in October 1953: "It was horribly complicated because Piaget insisted on speaking only in French" (Smedslund, 2013, p. 22). At this time, Piaget had already recruited Mays, who was traveling with him. This had already been contemplated when in early 1953 the Rockefeller Foundation asked if he would need a translator and assistant in the United States: "we believe that a subsidy intended to cover the costs for such exploration is perfectly possible" (Marshall, J. to J. Piaget, 9th January 1953). Before reading Introduction, Rockefeller, therefore, agreed to give Piaget the means to conduct, not the project itself, but its exploratory phase. This resulted in a handwritten document with the plan for a "genetic and operative" Epistemology Center-its first title-, written around March 1953.

After securing Mays' collaboration -as an interpreter and not simply as a translator- Piaget entered the realization phase: he wrote to Rockefeller with the aim of obtaining funds to work with Mays in the preparation of a final project for the Center. In response, in the spring of 1953 he obtained modest funding. On a trip to New York that lasted 10 days, at the end of March, he met with the members of the Foundation and with the editors of Basic Books (Swissair to J. Piaget, 17 December 1952; Freidberg, N. to J. Piaget, 18 February 1953). Upon his return, on April 21, he informed the Councilors of the State of Geneva, Albert Picot (Department of Public Instruction) and Louis Casaï (Department of Public Works) that he had received from Rockefeller "a certain amount to study, together with an assistant Anglo-Saxon, the possibility of creating an International Center of Genetic Epistemology" (Piaget, J. to A. Picot and L. Casaï, 21th April 
1953). In fact, he received from Rockefeller 7,500 CHF (approximately 1,800 USD) "for preliminary studies in genetic epistemology" (Rockefeller, 1953, p. 302) Piaget was always attentive to obtain the support of the political authorities for the development of his strategies -for example, for his appointment as a teacher (Ratcliff \& Borella, 2013)- and that time was not the exception.

Approximately towards the end of 1953, Piaget wrote a confidential report "about the European centers that are likely to collaborate with the future center of genetic epistemology" (Piaget, 1953). Aimed at detecting international candidates to contribute to the development of the CIEG, this report was a rare document in which it requested total confidentiality because the expressions were presented "with a certain frankness" and because the information came from "personal contacts and not only from the reading of the investigations". This writing was a synthesis of the scientific circulations carried out by Piaget since the post-war period, in which subjective and pragmatic images of the possible collaborators of Europe were offered.

He started with France: Bachelard, with his students, "could be of some help in some of our research (just as he helped Mr. Gonseth for the Zurich Center)". However, Bachelard "is a bit old and too fantasizing (in the good sense of the word) to analyze in detail the relationship between epistemology and genetic psychology". On the other hand, Piaget pointed out the importance of several circles in Paris, "whose work is closely related to genetic epistemology". There were two groups distinguished: first, the one led by Levi-Strauss, "dedicated to the applications of mathematics and logic in the social sciences" and that was concerned with the investigation of human structures. The second circle of interest was directed by Jean-Louis Destouches and his wife, Paulette Février, two physicists who applied logical models to science. Moving to Italy, his judgment was radical: "most Italian epistemologists are dogmatic philosophers and strangers to psychology". However, there was a "very lively center" created in Milan around Methodos and the linguist Silvio Ceccato who showed "a very curious and somewhat impressive spirit (he is the only one, with Arne Naess, who gives me this impression in Europe)". As for Switzerland, it only examined the case of Gonseth, who had developed a "very coherent" epistemological doctrine, although very open and too flexible. Gonseth had all the qualities that Ceccato lacked. "Very skilled, very practical, very ambitious, he was able to organize in Zurich a permanent center for discussions (International Forum Zurich), an international society of Logic and Philosophy of Sciences and a magazine (Dialectica)". For all these reasons, he affirmed that "the Geneva Center will have to work closely with him". In Belgium, Piaget contacted Feys, a professor of logic at Louvain who had published a review of Piaget's treatise on classes and 
numbers (Feys, 1948). It was someone "perfectly aware of American logic, but without originality or true creative spirit". On the other hand, he mentioned the logicians Devaud and Chaim Perelman, who studied the "non-formal processes used to convince others". In the Netherlands, Piaget characterized Beth for his pro-linguistic position and stopped to analyse the group created around Synthèse magazine. In his opinion, it was a magazine "little known because it works on the margins of universities and is run by very nice but impractical people". In England, Piaget was impressed, mainly, by the work of the people of Manchester and mentioned Polanyi, Turing and Mays, as well as a few English psychologists "interested in the relationship between logic and psychology". Since his meeting with Arne Naess in Norway, he was dazzled: "he is really the only researcher in Europe who does experimental epistemology and applies research methods comparable to those we use in Geneva". Indeed, although the fields differ, Naess was concerned with the common sense and thinking of scientists during their work of real and concrete discovery, something complementary to the study of the formation of notions in children. Finally, in Germany, he distinguishes the works of Dingler and in Austria those of Korner.

\section{The crystallization of the plan}

We can see that Piaget evaluated many intellectuals and post-war scholars with the help of a variety of qualitative criteria that give his report a unique authenticity. What is striking is both the subtlety of interpretation and the adaptation of the report to American pragmatism. Certainly it contained judgments about numerous colleagues, but Piaget was careful to balance the various criteria used without losing sight of the goal: to show Rockefeller his ability to evaluate, and not judge, the social dynamics, practical and intellectual forms of colleagues capable of being part of the center. The desired effect was undoubtedly achieved. A year later, during a trip from Piaget to the universities of Harvard and Princeton in October 1954, he noted the success of "viva voce" contacts (Piaget, J. to C. B. Fahs, 1th June 1954) with the members of Rockefeller. Piaget also maintained correspondence with Charles B. Fahs, another director of the Humanities Division of the Rockefeller Foundation (Piaget, J. to C. B. Fahs, 1th June 1954), and the relations of trust were thus established.

A few months before his trip to the United States, in June 1954, Piaget travelled to the Montreal Congress, where he was appointed president of the International Union of Scientific Psychology. During his return to Geneva, in mid-June, he devoted himself to "developing the detailed plan for a genetic epistemology" (Piaget, J. to C. B. Fahs, 
1th June 1954). All the stages, formal and informal, of the implementation of the project were scheduled since June. Princeton, where he is in mid-September, gave him the opportunity to present the project and personally speak with Edward F. d'Armes (Piaget, J. to C. B. Fahs, 1th June 1954), Associate Director of Humanities at Rockefeller, "in order to be sure to think about all the necessary details for the Foundation" (Piaget, J. to C. B. Fahs, 1th June 1954). On his return to Geneva, Mays proposes a new meeting and Piaget planned to make a new request: the support for the regular invitation of experts, for a period of one to two years, capable of collaborating in the investigations and discussions in Geneva. These were the moments of crystallization of the CIEG.

\section{The fulfilled utopia}

In mid-May 1955, the Rockefeller Foundation made the official announcement to the Reuters news agency of its donation of US \$ 69,000 to the University of Geneva -equivalent to 288,000 Swiss francs. With this initial endorsement, the Center opened its doors in October 1955 and then operated, co-financed, thanks to the periodic contributions of the Ford Foundation and the Swiss National Science Foundation (FNS). After the death of Piaget, and without having obtained the necessary financing to continue working (Hofstetter, Ratcliff, \& Schneuwly, 2012), the CIEG dissolved irreversibly in 1986. With a dynamic that sought to balance the formal with the informal, the Center developed a program of interdisciplinary research, systematic and calculated, although Piaget used to present it as a decontracting and marginal space with respect to the usual ways of the academy. In fact, the standard invitation letters that he sent to his colleagues to participate in the symposiums of the Center, warned of his style with the following formula: "they are completely informal". This modality was, however, a freedom with certain rules, typical of the knowledge industry.

During the years of its formation and then with the Center in full activity, Piaget's numerous trips through Europe, as well as its growing relations with the American continent, bore witness to a greater circulation to and from a previously peripheral Geneva. These circulations transformed the Swiss University into an epistemological epicenter during the heights of the Cold War, attracting researchers from all disciplines and from all over the world, including those from the Soviet bloc. It was also thanks to the CIEG that the so-called School of Geneva defined a circuit of displacements from the periphery to this new centrality, contributing, in this way, to the development of twentieth-century psychology. 


\section{References}

AA.VV. (1946). Manifeste pour la création de I'International Society for the study of Significs. Synthèse, 5(1/2), 96.

Anonyme (1954). Logic and psychology. Revue de Métaphysique et de Morale, 59, 459.

Apostel, L. (1982). Genetic Epistemology and Artificial Intelligence. Cahiers de la Fondation Archives J ean Piaget, 2, 97-134.

Beth, E. W. (1950). A propos d'un traité de logique. Methodos, 2, 258-264.

Beth, W. E., Mays, W., \& Piaget, J. (1956). Études d'épistémologie génétique I. Épistémologie génétique et recherche psychologique. Paris: PUF.

Bickhard, M. H. (1982). Automata Theory, Artificial Intelligence and Genetic Epistemology. Revue Internationale de Philosophie, 36(4), 549-566.

Borren, C. Van der. (10th November 1952). [Letter to J. Piaget] Archives Jean Piaget, Université de Genève (AJP-DFP/A1.282), Geneva, Switzerland.

Brief, J.-C. (1977). Le Constructivisme Piagétien et les épistémologies traditionnelles, Philosophiques, 4, 195-224.

Bronckart, J.-P. (1980). The International Center of Genetic Epistemology. French-Language Psychology, 1, 241-252.

Burman, J. T. (2013). Updating the Baldwin Effect: The biological levels behind Piaget's new theory, New Ideas in Psychology, 31(3), 363-373.

Carpintero, H., \& Peiro, J. M. (1977). La presencia de J. M. Baldwin en la psicología de J. Piaget. Revista de psicología general y aplicada, 32(147), 601-611.

Darbellay, F. (2011). Vers une théorie de I'interdisciplinarité ? Entre unité et diversité. Nouvelles Perspectives en Sciences Sociales, 7(1), 65-87.

Dell'Omodarme, M. R. (2014). Pour une épistémologie des savoirs situés. De l'épistémologie génétique de Jean Piaget aux savoirs critiques (Thèse de Doctorat en Philosophie). Université Paris, Panthéon Sorbonne, Paris.

Dionnet, S. (1998). Production de connaissance et interaction: Le cas du Centre international d'épistémologie génétique, Bulletin de psychologie, 51(3), 377-387.

Ducret, J.-J. (1983). Epistémologie, psychologie et histoire : à propos de la formation de la pensée de Jean Piaget. Cahiers de la Fondation Archives J ean Piaget, 4, 351-379.

Ducret, J.-J. (1998). Jean Piaget 1970-1980 : Dix dernières années de recherches sur le constructivisme au Centre international d'épistémologie génétique. Bulletin de psychologie, 51(3), 343375. 
Ducret, J.-J. (2000). Jean Piaget 1968-1979: une décennie de recherches sur les mécanismes de construction cognitive. Genève : Service de la recherche en éducation, 7.

Ducret, J.-J. (2011). Jean Piaget, un parcours à travers I'oeuvre. In M. Amann-Gainotti \& J.-J. Ducret (Eds.), Jean Piaget Psicologo Epistemologo Svizzero all'avanguardia (pp. 23-41). Roma: AEMME Publishing.

Ferreiro, E. (1975). Piaget. Los Hombres de la Historia. Buenos Aires: Centro Editor de América Latina.

Fetz, R. L. (1982). Pour une ontologie génétique. Jean Piaget et la philosophie moderne. Revue Internationale de Philosophie, 142$143,409-434$.

Feys, R. (1948). Classes relations et nombres. Journal of symbolic logic, 13(19), 56.

Fondation Archives Jean Piaget (1989). Bibliographie Jean Piaget. Genève: IRL.

Freidberg, N. (18th February 1953). [Letter J. Piaget] Archives Jean Piaget, Université de Genève (AJP-DFP/A1.177), Geneva, Switzerland.

Gagnon, M. (1977). Epistémologie génétique; science et philosophie. Philosophiques, 4, 225-244.

García, R. (2001). La epistemología: raíz y sentido de la obra de Piaget. In J. A. Castorina (Comp.), Desarrollos y Problemas en Psicología Genética (pp. 15-31). Buenos Aires: Eudeba.

Grize, J.-B. (1996). Sous la psychologie, l'épistémologie. In M. C. Assis, O. Z. M. Assis, \& Z. Ramozzi-Chiarottino (Eds.), Piaget: Teoria e Prática (pp. 3-7). Campinas: Tecnicópias Gráfica e Editora.

Hofstetter, R. (2010). Genève: creuset des sciences de l'éducation. Genève: Droz.

Hofstetter, R., Ratcliff, M. J., \& Schneuwly, B. (2012). Cent ans de vie. La faculté de psychologie et des sciences de I 'éducation héritière de I 'Institut Rousseau et de I 'ère piagétienne. Genève: Georg.

Kesselring, T. (1981). Entwicklung und Widerspruch: Ein Vergleich zwischen Piagets genetischer Erkenntnistheorie und Hegels Dialektik. Frankfurt: Suhrkamp.

Marshall, J. (9th January 1953). [Letter to J. Piaget] Archives Jean Piaget, Université de Genève (AJP-DFP/A1.964), Geneva, Switzerland.

Matsuda, T. (2007).Soft Power and its Perils: U.S. Cultural Policy in Early Postwar Japan and Permanent Dependency. Stanford: Stanford University Press.

Mays, W. (22th Ferbruary 1953). [Letter to Jean Piaget] Archives Jean Piaget, Université de Genève (AJP-DFP/A1.185), Geneva, Switzerland. 
Mays, W. (11th August 1953). [Letter to Jean Piaget] Archives Jean Piaget, Université de Genève (AJP-DFP029782), Geneva, Switzerland.

Monnier, C., \& Wells, A. (1982). Note sur les travaux récents du Centre international d'épistémologie génétique: de la prise de conscience aux raisons. Cahiers de la Fondation des Archives J ean Piaget, 2-3, 295-329.

Perri, G. (1996). Crescita della conoscenza e complessità: II costruttivismo in Piaget, nell'epistemologia francese e nella scienza, I. Napoli: Edizioni Scientifiche Italiane.

Piaget, J. (1923). Le langage et la pensée chez l'enfant. Neuchâtel et Paris: Delachaux et Niestlé.

Piaget, J. (1936). La naissance de l'intelligence chez l'enfant. Neuchâtel et Paris: Delachaux et Niestlé.

Piaget, J. (1938). La réversibilité des opérations et l'importance de la notion de «groupe » pour la psychologie de la pensée. Onzième congrès international de psychologie, s.n,433-435.

Piaget, J. (1942). Classes, relations et nombre. Essai sur les groupements de la logistique et sur la réversibilité de la pensée. Paris: Vrin.

Piaget, J. (1949). Traité de logique. Paris: Colin.

Piaget, J. (1950a). Introduction à l'épistémologie génétique I. Paris: PUF.

Piaget, J. (1950b). Introduction à l'épistémologie génétique II. Paris: PUF.

Piaget, J. (1950c). Introduction à l'épistémologie génétique III. Paris: PUF.

Piaget, J. (1952). Essai sur les transformations des opérations logiques. Paris: PUF.

Piaget, J. (1953). Logic and psychology. Manchester: Manchester University Press.

Piaget, J. (1953a). Projet d'un Centre international d'épistémologie génétique et opérationnelle. Archives Jean Piaget, Université de Genève (AJP-DFP/A2.1.1328), Geneva, Switzerland.

Piaget, J. (1953b). Confidential. Bref rapport sur les centres européens d'Epistémologie susceptibles de collaborer avec le futur centre d'Epistémologie génétique de Genève. Archives Jean Piaget, Université de Genève (AJP-DFP/A2.1.1326), Geneva, Switzerland.

Piaget, J. (21th April 1953). [Letter to Albert Picot and Louis Casaï] Archives Institut Jean-Jacques Rousseau (AIJJR FG.F.5.1/1.1953), Geneva, Switzerland.

Piaget, J. (18th May 1954). [Letter to Dr. D. Vuysje] Archives Institut Jean-Jacques Rousseau (AIJJR FG.F.5.1/1.1954), Geneva, Switzerland. 
Piaget, J. (1th June 1954). [Letter to Charles B. Fahs] Archives Institut Jean-Jacques Rousseau (AIJJR FG.F.5.1/1.1954), Geneva, Switzerland.

Piaget, Jean. (16th June 1954). [Letter to W. Mays] Archives Institut Jean-Jacques Rousseau (AIJJR FG.F.5.1/1.1954), Geneva, Switzerland.

Polanyi, M. (6th March 1953). [Letter to J. Piaget] Archives Jean Piaget, Université de Genève (AJP-DFP/A1.178), Geneva, Switzerland.

Ratcliff, M. J. (2011). Entre autorité, recherche et sociabilités: Jean Piaget et I'Institut Rousseau 1920-1940. In M. Amann Gainotti, \& J.-J. Ducret (Eds), Jean Piaget Psicologo Epistemologo Svizzero all'avanguardia, atti delle giornate di studio Istituto Svizzero di Roma, (pp.83-97). Roma : AEMME Publishing.

Ratcliff, M. J. (2016). Heurs et malheurs d'une tentative de modélisation. Jean Piaget et la formalisation des structures de l'esprit (1937-1972). In: C. Blanckaert, J. Léon, \& D. Samain (Eds.), Modélisations et sciences humaines, figurer, interpréter, simuler (pp. 333-351). Paris: I'Harmattan.

Ratcliff, M. J., \& Borella, P. (2013). Voilà donc une chaire désaxée; La nomination de Jean Piaget à I'Université de Genève. Revue suisse d'histoire, 63, 1-18.

Rockefeller Foundation. (1953). Annual Report. New York: Rockefeller Foundation.

Smedslund, J. (2013). From Nonsense Syllables to Holding Hands, Sixty Years as a Psychologist. Ohio: Taos Institute publications.

Smith, L. (1994). The Binet-Piaget connection: Have developmentalists missed the epistemological point? Archives de psychologie, 62, 275-285.

Swissair. (17th December 1952). [Letter to Jean Piaget]. Archives Jean Piaget, Université de Genève (AJP-DFP/A1.222), Geneva, Switzerland.

Vidal, F. (1996). Piaget Before Piaget. Cambridge: Harvard University Press.

Vonèche, J. (1985). Genetic epistemology in the context of evolutionary epistemology. In: J. C. Pitt Dordecht (Ed.), Change and Progress in Modern Science (pp. 199-232). USA: Reidel.

Vonèche, J. (1993). Aspects épistémologiques des relations interdisciplinaires. In W. Arber (Ed.), Inter- und Transdisziplinaritàt, warum? - wie? (pp. 111-128). Bern: Haupt.

Vonèche, J. (1996). Piaget's first theory of equilibrium (1918). In L. Smith (Ed.), Critical Readings on Piaget (pp. 1-19). London: Routledge/Taylor \& Francis. 


\section{Endereço para correspondência}

\section{Marc J. Ratcliff}

Archives Jean Piaget and FPSE, University of Geneva, Switzerland

UniMail 40, Boulevard du Pont d'Arve, 1211

Endereço eletrônico: marc.ratcliff@unige.ch

\section{Ramiro Tau}

FPSE, University of Geneva, Switzerland

UniMail 40, Boulevard du Pont d'Arve, 1211

Endereço eletrônico: ramiro.tau@unige.ch

Recebido em: $21 / 12 / 2018$

Aceito em: 14/02/2019

\section{Notas}

* Doctor in Psychology - Doctor in History of Science.

** Doctor in Psychology.

${ }^{1}$ Our translation.

Funding: Swiss National Science Foundation (SNSF), Project 100011-175617.

Este artigo de revista Estudos e Pesquisas em Psicologia é licenciado sob uma Licença Creative Commons Atribuição-Não Comercial 3.0 Não Adaptada. 